\title{
Analisis Pengembangan dan Implementasi System E-learning Untuk Meningkatkan pengetahuan Agent Menggunakan Metode ADDIE Model (Study Kasus: PT.Global Infotech Solution)
}

\author{
Nansy Stephanie Mongi, Hendry* \\ Fakultas Teknologi Informasi, Teknik Informatika, Universitas Kristen Satya Wacana, Salatiga, Indonesia \\ Email: ${ }^{1}$ nancysmongi@gmail.com, ${ }^{2, *}$ hendry@uksw.edu \\ Submitted: 12/03/2021; Accepted:28/04/2021; Published: 30/05/2021
}

\begin{abstract}
Abstrak-Pengembangan system e-learning di perusahaan sangat penting dalam proses pembelajaran dan pelatihan karyawan atau agent untuk mencapai tujuan perusahaan. Seperti di PT. Global Infotech Solution dimana proses pembelajaran masih manual sehingga menghambat pembelajaran karena untuk mengadakan pelatihan menimbulkan biaya yang cukup besar bagi agent yang berada diluar daerah. Oleh karena itu perusahaan membutuhkan system e-learning untuk membantu proses pembelajaran agent karyawan agar lebih efektif. System e-learning telah dikembangkan dan diimplementasikan dengan menggunakan platform moodle yang merupakan salah satu system manajemen pembelajaran. Metode pengembangan yang digunakan adalah ADDIE model (analysis, design, implementation, evaluation) sehingga lebih cepat dalam mengembangkan platform system e-learning sesuai dengan kebutuhan pengguna di perusahaan. Hasil penelitian system e-learning dinilai melalui tanggapan agent karyawan dari aspek pembelajaran sebesar 84,75\% dengan kategori baik, dilihat dari aspek tampilan sebesar 86,05\% dengan kategori sangat baik, dilihat dari aspek System e-learning menggunakan platform moodle sebesar 80,32\% dengan kategori baik, dan yang terakhir dilihat dari aspek materi yang ada dalam system e-learning dengan konsep yang menarik sebesar $89,82 \%$ dengan kategori sangat baik. Jadi secara keseluruhan penilaian kualitas system e-learning secara keseluruhan sebesar 85,25 dengan kategori baik. Berdasarkan hasil penelitian yang dilakukan, Dengan system e-learning ini, proses pembelajaran akan lebih efisien dalam menampilkan informasi pembelajaran yang dibutuhkan oleh agent perusahaan dan dapat diakses oleh pengguna secara online selama terkoneksi dengan internet.
\end{abstract}

Kata Kunci: Agent; ADDIE; E-Learning; Moodle; Pengembangan

Abstract-The development of e-learning system ini companies is very important in the learning process and training of employees or agents to achieve company goals. Like at PT. Global Infotech solution where the learning process still uses manuals so that it hinders learning because to hold training is quite large ini incurring costs for agents who are outside the region. Therefore companies need an e-learning system to help the employee agent learning process to be more affective. Elearning system have been developed and implemented using the moodle platform, which is one of the learning management system. The development method used is the ADDIE (Analysis, Design, Implementation, Evaluation) model so that it is faster ini developing an e-learning system platform according to user needs in the company. The results of the e-learning system research were assessed through employee agent responses from the learning aspect of $84.75 \%$ with a good category, seen from the display aspect of $86.05 \%$ with the very good category, seen from the aspect of the e-learning system using the Moodle platform of $80,32 \%$ with a good category, and the last one seen from the material aspect in the e-learning system with an interesting concept of $89.82 \%$ with the very good category. So the overall assessment of the quality of the e-learning system as a whole is 85.25 with a good category. With this e-learning system, the learning process will be more efficient in displaying learning information needed by company agents in a web-based form and can be accessed by users online as long as they are connected to the internet.

Keywords: Agent; ADDIE; E-Learning; Moodle; Development

\section{PENDAHULUAN}

Dengan memanfaatkan kecanggihan teknologi informasi, sistem manajemen pengetahuan di perusahaan dapat digunakan secara efisien dan efektif untuk proses pembelajaran itu sendiri. Pembelajaran merupakan strategi sekaligus solusi bagi suatu perusahaan maupun individu untuk beradaptasi dan mengambil tindakan yang efektif untuk menciptakan keunggulan daya saing. Tujuan utama system manajemen pengetahuan adalah meningkatkan kompetensi pegawai/agent perusahaan sebagai bagian dari pengelolaan sumber daya manusia. E-learning teknologi dapat digunakan untuk mendukung usaha-usaha pengajaran lewat teknologi elektronik internet dan dapat lmembuat sebuah proses pembelajaran kedalam bentuk digital yang di jembatani oleh teknologi internet. Saat ini e-learning telah banyak di implementasikan menggunakan perangkat lunak yang disebut learning management system seperti moodle. Moodle adalah sebuah paket perangkat lunak yang berguna untuk membuat dan mengadakan pelatihan dan pendidikan berbasis internet. Moodle juga adalah software open source yang mendukung implementasi $e$-learning dimana fitur-fitur moodle yang ada dipakai untuk menunjang pembelajaran suatu agent perusahaan. Persiapan sebelum pengembangan dan implementasi e-learning memegang peran penting demi kelancaran proses pembelajaran berbasis web [1]. Berdasarkan hasil penelitian dan pengembangan terdahulu maka penulis mencantukmakan hasil penelitian yang memiliki relevansi atau keterkaitan dengan penelitian yang akan dilakukan menurut N. Nirsal(2019),populasi dalam penelitian ini adalah sekolah menengah atas yang mengatakan Kevalidan pada media pembelajaran berbasis e-learning diperoleh dari validasi instrumen yang dilakukan oleh validator ahli media dan ahli materi. Kepraktisan diperoleh dari hasil lembar observasi siswa dan guru terhadap media serta lembar keterlaksanaan penggunaan media sedangkan keefektifan diperoleh berdasarkan 
hasil evaluasi siswa dan respon dari siswa dan guru.

Seperti halnya pada PT. Global Infotech Solution adalah perusahaan yang bergerak dalam pelayanan jasa konsultan pemrograman komputerisasi pembuatan webdesign \& event management. Proses pembelajaran Agent di perusahaan ini masih dilakukan secara tatap muka. Dikarenakan perusahaan mempunyai banyak cabang sehingga biaya yang dikeluarkan perusahaan untuk mengadakan 1 event training cukup besar, mulai dari biaya transportasi hingga biaya penginapan bagi agent yang berada di luar daerah dan hanya dibagikan melalui social media. Dengan melihat masalah yang dihadapi oleh perusahaan PT.Global Infotech Solution, maka penelitian ini bertujuan untuk mengembangkan dan mengimplementasikan system e-learning bernama "Belajar DNAku.id" menggunakan software moodle dengan metode pengembangan ADDIE Model. Sehingga nantinya system elearning ini dapat membantu dan mempermudah inclass training perusahaan dalam melakukan pembelajaran bagi agent Perusahaan dan apabila system e-learning tersebut sudah dikembangkan dan diimplementasikan maka perusahaan dapat melakukan efisiensi yang cukup besar dan berdampak baik bagi perusahaan.

\section{METODE PENELITIAN}

\subsection{ADDIE Model}

Metode penelitian ini menjelaskan mengenai system yang digunakan dalam analisis pengembangan dan implementasi system e-learning. Metode penelitian yang dipakai adalah ADDIE model. ADDIE model merupakan sebuah aktivitas pembelajaran yang memiliki karakter interaktif dengan beberapa langkah dasar pembelajaran yang efisien dinamis dan efektif. model $A D D I E$ ini bisa menjadi panduan untuk mengembangkan sebuah fasilitas strategi pembelajaran untuk membantu performa pembelajaran. ADDIE model juga dalam mendesain system menggunakan pendekatan system dalam membagi proses perencanaan pembelajaran ke beberapa langkah-langkah dalam urutan yang tentunya logis, kemudian output-output dari setiap langkah sebagai input untuk langkah selanjutnya. ADDIE model terdiri dari 5 fase yaitu analysis, design, developmet, implementation, dan evaluation. Ide ADDIE adalah untuk membangun system pembelajaran yang efektif dan akan menerima feedbacknya secara berkelanjutan dan diharapkan dengan adanya model ini dapat menghemat waktu dan biaya dengan menangkap permasalahan saat permasalahan tersebut masih dapat diperbaiki. [2]

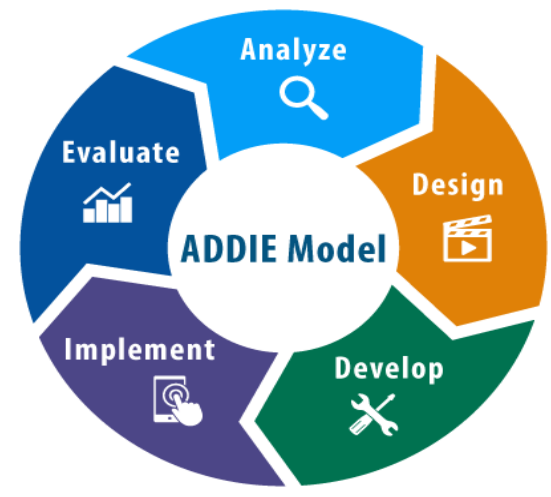

Gambar 1. ADDIE Model (sumber: edapp.com, 2020)

Tahapan yang dilakukan dalam ADDIE Model untuk menerapkan analisis pengembangan dan implementasi system e-learning berbasis web menggunakan platform moodle diawali dengan tahapan Analisis (Analysis). ). Pada tahapan analisis, perlunya menganalisis pengembangan ini ada beberapa yang harus dilakukan adalah mencari masalah didalam proses pembelajaran, kebutuhan yang diperlukan, tujuan pembelajaran, dan juga mempertimbangkan setiap kendala, lingkungan, waktu, dan media dalam menyampaikan pembelajaran. Pada tahapan Desain (Design) berhubungan dengan memutuskan isi, latihan, alat penilaian dan analisis yang berhubungan dengan tujuan pembelajaran. Dalam tahapan ini juga dapat dibuat, tampilan, desain grafis, dan user interface. Selanjutnya tahapan Pengembangan (Development). ). Pada tahapan ini pengembang lah yang menjadi kunci utama yang sangat penting dalam pembuatan web e-learning ini guna mencapai tujuan dari tahap analisis dan desain. Dalam tahapan Implementasi (Implementation) penelitian ini mengimplementasikan rancangan bahan pembelajaran yang telah dikembangkan dimulai dari analisis masalah, desain user interface(UI), Dashboard, dan Report. Setelah diterapkan dalam bentuk pembelajaran kemudian dilakukan evaluasi awal untuk mendapatkan umpan balik pada penerapan pengembangan. Tahapan selanjutnya adalah Evaluasi(evaluation) Pada tahapan evaluasi merupakan langkah akhir dari desain analisis pengembangan model $A D D I E$. Evaluasi adalah proses untuk melihat apakah system pembelajaran yang dibangun berhasil, sesuai dengan harapan awal atau tidak. Evaluasi sebenarnya terjadi pada 4 tahapan diatas. Aktivitas yang dilakukan pada fase evaluasi ini adalah untuk melihat kembali dampak pembelajaran dengan cara yang kritis, mengukur ketercapaian tujuan pengembang produk, dan mengukur apakah apa yang telah mampu dicapai. [3] 


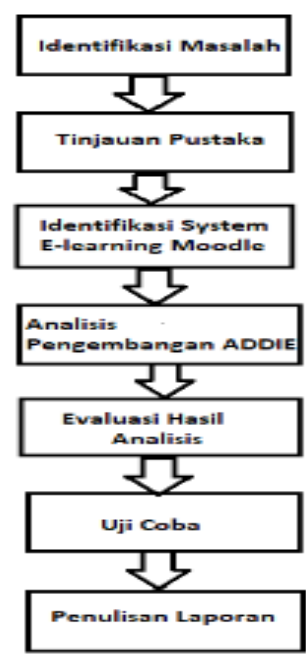

Gambar 2. Tahapan penelitian dengan metode ADDIE model

Tahap-tahap penelitian dan analisis pengembangan system e-learning diawali dengan Identifikasi Masalah dimana dalam pembelajaran (training) agent perusahaan masih dilakukan secara tatap muka, dikarenakan perusahaan mempunyai banyak cabang sehingga biaya yang dikeluarkan perusahaan untuk mengadakan 1 event training cukup besar, mulai dari biaya transportasi hingga biaya penginapan bagi agent yang berada di luar daerah dan bahkan hanya dibagikan melalui media social sehingga diperlukan sebuah media training pembelajaran yang akan memudahkan dalam melakukan inclass training kedalam bentuk yang lebih efisien Tahap tinjauan pustaka ini adalah mencari jurnal dan artikel yang berkaitan dengan penelitian ini. Pada tahapan identifikasi system ini dilakukan dengan langsung menginstall platform software moodle untuk menganalisis kebutuhan Agent perusahaan dalam proses inclass training berbasis web ke dalam bentuk Learning management system(LMS). Setelah mengidentifikasi selanjutnya adalah menganalisis pengembangan dan implementasi menggunakan metode ADDIE model yang terdiri dari 5 fase tahapan yaitu Analysis, Design, Development, Implementation, dan Evaluation. Setelah membuat analisis pengembangan ADDIE model kemudian hasil dari analisis ini di presentasikan ke client dan apabila ada yang perlu ditambahkan dari pihak client dengan pengembangan yang dibuat dan jika sudah disetujui oleh client dengan metode pengembangan ADDIE model bisa masuk ke dalam proses uji coba e-learning. Bila ada perubahan akan dilakukan oleh developer sehingga sesuai dengan yang diharapkan pada tahapan analisis dan desain. Setelah platform e-learning sesuai yang diharapkan sudah jadi selanjutnya adalah melakukan uji coba yang dilakukan developer, apakah kebutuhan e-learning sesuai dengan requirement yang sudah di tentukan. Tetapi jika ada revisi akan dilakukan pengecekan kembali sesuai dengan kebutuhan pembelajaran agent perusahaan. Tahapan terakhir adalah penyusunan laporan. Didalam penyusunan laporan akan berisi semua tahapan pengembangan dan proses yang dilakukan oleh peneliti sehingga dapat membuat laporan hasil penelitian yang telah dilakukan.

\subsection{Teknik Analisis Data}

Pada metode penelitian ini penulis melakukan pengumpulan data adalah dengan observasi ke perusahaan (konsultasi design dan pengembangan system e-learning) dan memberikan angket validasi dari tanggapan karyawan perusahaan. Setelah data terkumpul kemudian akan dihitung hasilnya dan akan di prensentasekan dengan rumus:

$$
\mathrm{P}=\frac{\mathrm{f}}{\mathrm{N}} \mathrm{X} 100 \%
$$

Keterangan:

$\mathrm{F}=$ Frekuensi yang dicari presentasenya.

$\mathrm{N}=$ Jumlah frekuensinya (banyak individu)

$\mathrm{P}=$ Angka persentase

Hasil penilaian kelayakan kualitas produk kemudian diberikan kriteria sebagai berikut:

Tabel 1. Persentase dan Kriteria Kelayakan Media

\begin{tabular}{ccc}
\hline No & Rentang Persentase & Kriteria \\
\hline 1 & $86 \%-100 \%$ & Sangat Baik \\
2 & $76 \%-85 \%$ & baik \\
3 & $60 \%-75 \%$ & Cukup \\
4 & $0 \%-59 \%$ & Tidak baik \\
\hline
\end{tabular}




\subsection{E-Learning}

E-Learning adalah sistem atau juga konsep pembelajaran yang memanfaatkan suatu teknologi informasi dalam suatu proses belajar mengajar yang berbasis elektronik. Salah satu media yang digunakan adalah jaringan computer. Dengan penyajian e-learning berbasis web ini bisa menjadi lebih interaktif. Banyak pakar yang menguraikan definisi e-learning dari berbagai sudut pandang seperti yang dikatakan Michael(2013) bahwa $e$ learning adalah pembelajaran yang disusun dengan tujuan menggunakan suatu system elektronik atau computer sehingga mampu untuk mendukung suatu proses pembelajaran. Manfaat yang dimiliki e-learning juga antara lain seperti efisiensi biaya dan sangat fleksibel dalam memilih waktu juga tempat untuk dapat mengakses selama diperjalanan [4].

\subsection{Agent}

Agent adalah seseorang atau badan yang diberi kuasa atau yang ditunjuk untuk mewakili atau bertindak dengan mempunyai hubungan tetap. Agent dalam perusahaan atau lembaga yang bertindak sebagai perantara untuk dan atas nama principal (perorangan atau badan usaha) berdasarkan perjanjian untuk melakukan pemasaran tanpa melakukan pemindahan hak atas fisik barang dan jasa yang dimiliki oleh principal yang menunjuknya [5].

\subsection{Moodle}

Moodle adalah sebuah platform yang bersifat web-based. Jadi seluruh kegiatan belajar mengajar dilakukan dengan mengakses website menggunakan browser. Platform ini juga bersifat open source dan dapat digunakan secari lebih efektif. banyak lembaga pendidikan menggunakan moodle. Namun, sekarang banyak perusahaan besar yang menggunakan moodle sebagai media belajar para karyawan/agent di perusahaan. Ada beberapa kelebihan menggunakan moodle adalah mudah digunakan karna didalamnya memiliki fitur drag-and-drop, fleksibel, aman, terintegrasi, mendukung plugin, mobile friendly, dan dapat mendukung dari berbagai Bahasa [6].

\section{HASIL DAN PEMBAHASAN}

\subsection{Penerapan Metode ADDIE Model Dalam System E-elearning}

Mengembangkan bahan ajar membutuhkan model pengembangan yang berpengaruh dalam implementasi hasilnya. Dalam teori ADDIE model merupakan salah satu pengembangan bahan ajar yang sesuai demi menjamis kualitas system e-learning. Pengembangan ADDIE model ini merupakan proses yang sudah umum untuk digunakan oeh pengembang. Ada lima tahapan, yaitu analisis, desain, pengembangan, implementasi dan evaluasi untuk memenuhi proses pengembangan system e-learning tersebut. Model pengembangan ini juga menggunakan output dari setiap angkah sebagai input pada langkah selanjutnya yang akan dijelaskan lebih rinci melalui tahapantahapan dalam pengembangan, yaitu:

\section{a. Analisis (Analysis)}

Dalam tahapan ini adalah analisis dari permasalahan yang dihadapi oleh perusahaan dimana agent karywan membutuhkan pembelajaran untuk meningkatkan kualitas perusahaan. Analisis tujuan pembelajaran adalah langkah yang di perlukan untuk meningkatkan pengetahuan agent karyawan dalam mempelajari produk-produk mengunakan system e-learning perusahaan.

\section{b. Desain (Design)}

Tahapan desain yang dimaksud disini adalah perencanaan pengembangan bahan ajar yang diantaranya bertujuan untuk memenuhi scenario pemebelajaran, pemiihan konsep pembelajaran, dan juga merancang tampilan materi bahan ajar berdasarkan fakta, prinsip, prosedur, dan waktu pembelajaran . penulis mengambarkan design tampilan menggunakan figma untuk menyesuaikan dengan kebutuhan system e-learning pembelajaran berbasis web.

\section{c. Pengembangan(Development)}

Dalam tahapan pengembangan bahan ajar penulis menggunakan Learning Management System Moodle yang merupakan salah satu platform system e-learning yang kemudian dikembangkan oleh ADDIE model. Tujuan yang perlu dicapai dalam tahapan pengembangan ini adalah:

1. Mengembangkan system e-learning yang akan digunakan guna mencapai tujuan pembelajaran seperti yang di tuliskan dalam tahapan desain.

2. Memilih konsep bahan ajar terbaik untuk mencapai tujuan pembelajaran.

3. Bentuk konsep bahan ajar harus dimodifikasi dengan tujuan pembelajaran

\section{d. Implementasi(Implementation)}

Tahapan Implementasi dalam penelitian ini adalah tahapan untuk mengimplementasikan system e-learning yang telah dikembangkan sesuai dengan kebutuhan system e-learning. Pada saat implementasi rancangan yang telah 
dibuat selanjutnya diterapkan pada kondisi pembelajaran. Setelah diterapkan system e-learning ini kemudian dilakukannya evaluasi pertama untuk memberikan feedback dalam penerapan pengembangan selanjutnya.

\section{e. Evaluasi(Evaluation)}

Evaluasi merupakan tahapan terakhir dari metode pengembangan system e-learning menggunakan ADDIE model untuk memberikan nilai terhadap pengembangan yang telah dilakukan. Hasil evaluasi digunakan untuk memberikan feedback kemudian jika terdapat revisi yang dibuat sesuai dengan hasil kebutuhan yang belum dapat terpenuhu dalam tujuan pengembangan.

\subsection{Hasil Penelitian}

System e-learning yang dihasilkan dari penelitian ini di beri nama "Belajar.DNAku.id" sebagai media pembelajaran untuk agent karyawan. Dalam system e-learning ini terdapat beberapa materi, quiz, contet interactive h5p yang dapat memberikan konsep yang menarik dalam melakukan pembeajaran dan dapat diakses melalui smartphone dan PC. Media pembelajaran ini berbasis web yang dapat diakses dimana saja selama terhubung dengan internet. Berikut adalah table hasil observasi penulis terhadap tanggapan hasil angket agent karyawan.

Tabel 2. Hasil uji coba menurut angket agent karyawan

\begin{tabular}{ccc}
\hline No & Aspek & Presentase \\
\hline 1 & Pembelajaran & $85 \%$ \\
2 & Tampilan & $86 \%$ \\
3 & System e-learning LMS Moodle & $80 \%$ \\
4 & Materi & $90 \%$ \\
\hline
\end{tabular}

Hasilobservasi penilaian system e-learning dinilai melalui tanggapan agent karyawan dari aspek pembelajaran sebesar $84,75 \%$ dengan kategori baik, dilihat dari aspek tampilan sebesar 86,05\% dengan kategori sangat baik, dilihat dari aspek System e-learning menggunakan platform moodle sebesar 80,32\% dengan kategori baik, dan yang terakhir dilihat dari aspek materi yang ada dalam system e-learning dengan konsep yang menarik sebesar 89,82\% dengan kategori sangat baik. Jadi secara keseluruhan penilaian kualitas system e-learning secara keseluruhan sebesar 85,25 dengan kategori baik. Berdasarkan hasil penelitian yang dilakukan, dalam system elearning ini kelebihannya adalah sudah terdapat fitur-fitur materi secara lengkap dengan konsep tampilan yang menarik dan mudah digunakan melalui mobile dan PC selama terhubung dengan internet.

\subsection{Use Case Implementasi E-Learning}

Pengembangan dan implementasi system e-learning berbasis web menggunakan use case diagram. Use case menjelaskan interaksi yang terjadi antara actor dengan system yang ada, sebuah usecase direpresentasikan dengan urutan langkah yang sederhana.

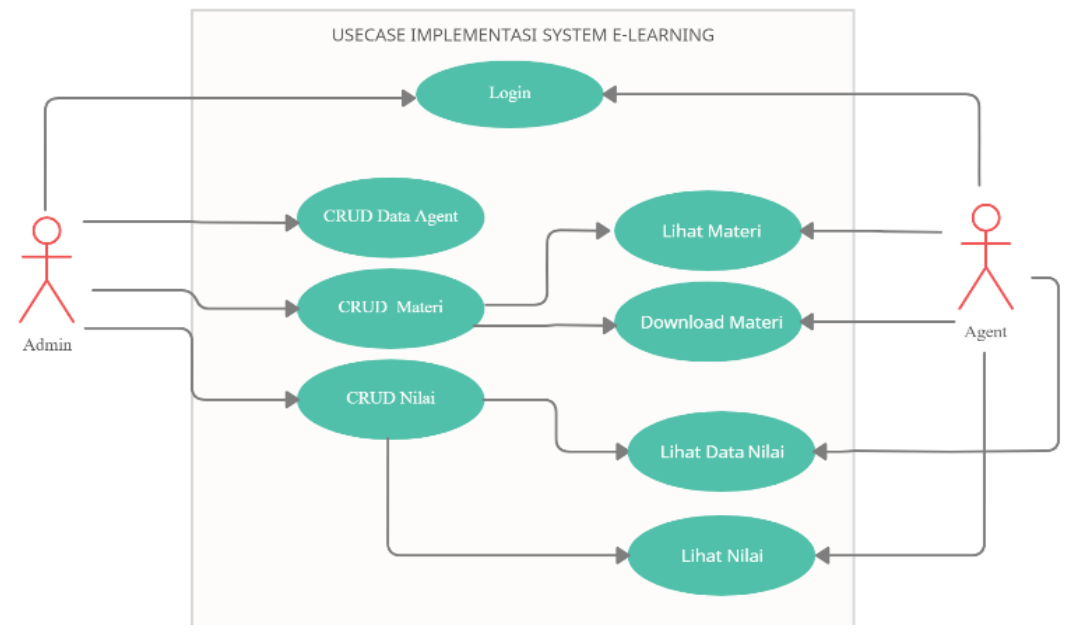

Gambar 3. Use Case Implementasi E-learning

Dalam use case diagram diatas terdapat dua actor yang berperan dalam system e-learning ini. Actor pertama adalah admin, dimana admin dapat melakukan CRUD (Create, Read, Update, Delete) terhadap data agent, data materi dan data nilai. Actor admin juga dapat melihat materi dan nilai dan dapat melakukan CRUD terhadap data agent dan dapat memperbarui data agent. Actor yang berperan lainnya adalah agent, dimana agent dapat melihat materi dan melihat data nilai. Admin Dan agent juga dapat mengunduh materi sehingga jika terjadi sesuatu yang tidak diinginkan data materi didalam system dapat ter backup.

\subsection{Analisis Kebutuhan Fungsional dan Non-Fungsional E-Learning}


Dalam kebutuhan fungsional dan non-fungsional merupakan kebutuhan penting dalam menganalisis pengembangan sebuah system informasi termasuk system e-learning ini. Kebutuhan fungsional ini dianalisis guna mengetahui apa yang diharapkan pada pada system setelah dikembangkan dan akan dikembangkan. Dalam metode pengembangan ADDIE Model ini untuk mengetahui kebutuhan fungsional dan non fungsional terdiri dari admin dan juga agent perusahaan. Berikut adalah hasil dari analisis kebutuhan pengguna (user requirement) system elearning yang disajikan pada tabel berikut [7].

Tabel 3. Kebutuhan fungsional pengguna (user requirement)

\begin{tabular}{|c|c|c|}
\hline No & $\begin{array}{c}\text { Kebutuhan } \\
\text { pengguna }\end{array}$ & Deskripsi hasil analisis \\
\hline 1 & Input & $\begin{array}{l}\text { - Admin dapat mengubah pengaturan system sesuai kebutuhan e- } \\
\text { learning }\end{array}$ \\
\hline 2 & Output & $\begin{array}{l}\text { - } \quad \text { System e-learning dapat menampilkan materi, test, dan quiz } \\
\text { - } \quad \text { Dapat menyediakan informasi website e-learning }\end{array}$ \\
\hline 3 & Proses & - $\quad$ Mendukung penyimpanan semua data \\
\hline 4 & Performance & - Cepat dan mudah diakses dimana saja saat terhubung dengan internet \\
\hline 5 & Control & $\begin{array}{l}\text { - System e-learning dapat memberikan keamanan akses melalui proses } \\
\text { login dan disertai verifikasi password. }\end{array}$ \\
\hline
\end{tabular}

Tabel 4. Kebutuhan non-fungsional media ajar system e-learning

\begin{tabular}{ccc}
\hline No & Kebutuhan & Deskripsi \\
\hline 1 & Sistem operasi & Microsoft windows \\
2 & Platform & Moodle \\
3 & Server & Localhost \\
\hline
\end{tabular}

\subsection{Impelementasi Program}

Adapun hasi dari pengembangan dan implementasi system e-learning belajar DNAku pada studi kasus PT.Global infotech solution adalah penerapan implementasi berbasis web. System e-learning yang dikembangkan pada perusahaan ini menggunakan software platform moodle $v 3.9$.

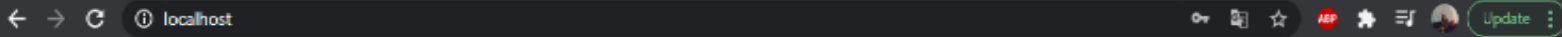

\#DNAku Tentang kami Kursus *
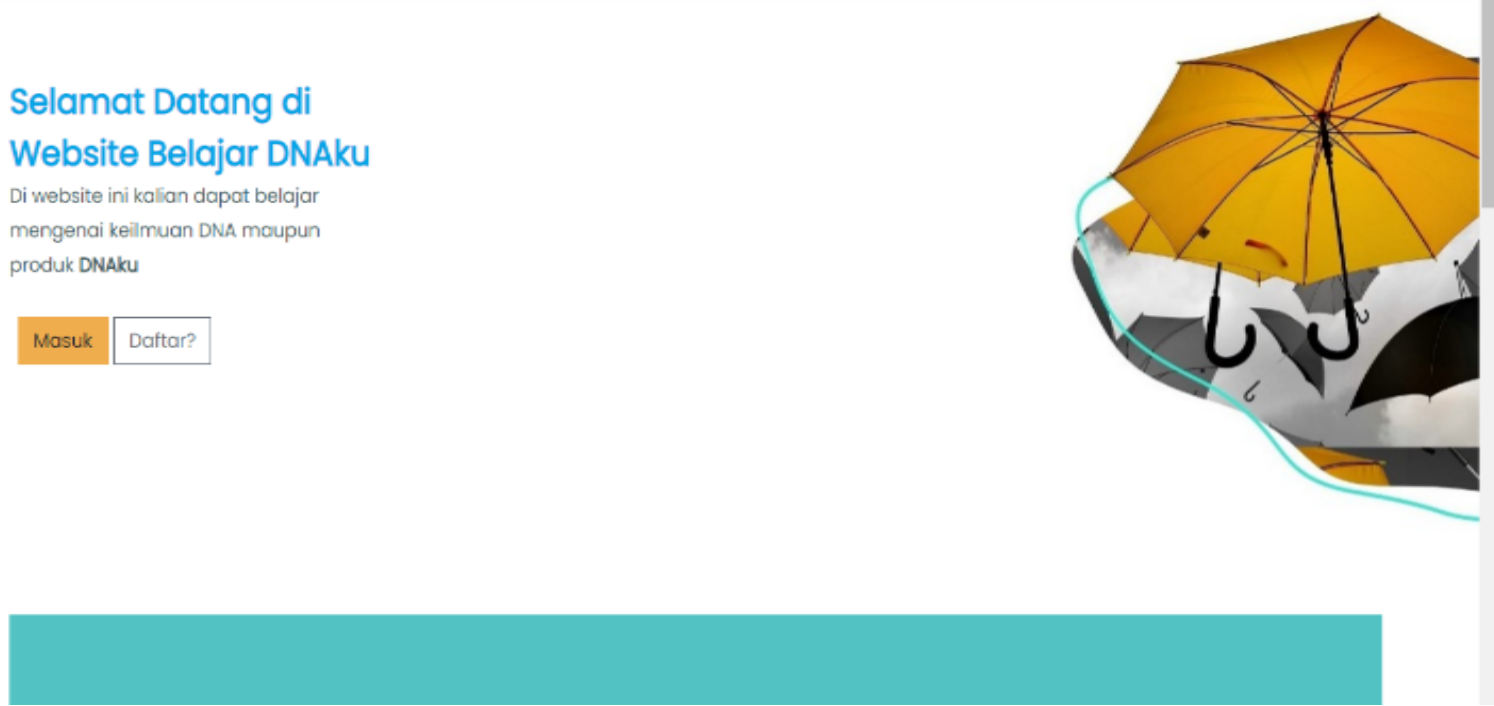

Gambar 4. Tampilan Utama e-learning

Pada gambar 4 merupakan tampilan dari halaman utama yang telah di desain oleh developer menggunakan tahapan metode ADDIE model yang berisi info tujuan dari system e-learning untuk agent perusahaan. Didalam frontpage user akan mendapatkan info tentang perusahaan dan terdapat beberapa kursus di bagian header. Selanjutnya user akan melakukan login jika sudah terdaftar. Tapi jika sebaliknya user akan masuk ke menu daftar untuk menghubungi administrator dan akan diberikan username dan paswoard untuk masuk. 


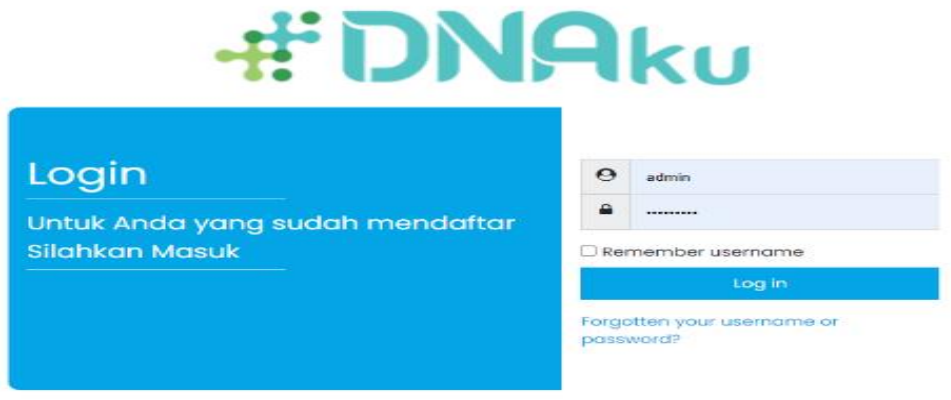

Gambar 5. Tampilan Logi

Pada gambar 5, tampilan login adalah tampilan untuk masuk ke system e-learning belajar agent DNAku.id di PT.Global infotech solution. Untuk user yang sudah terdaftar dan sudah mendapatkan username dan paswoard akan dapat masuk ke system e-learning dengan klik login.

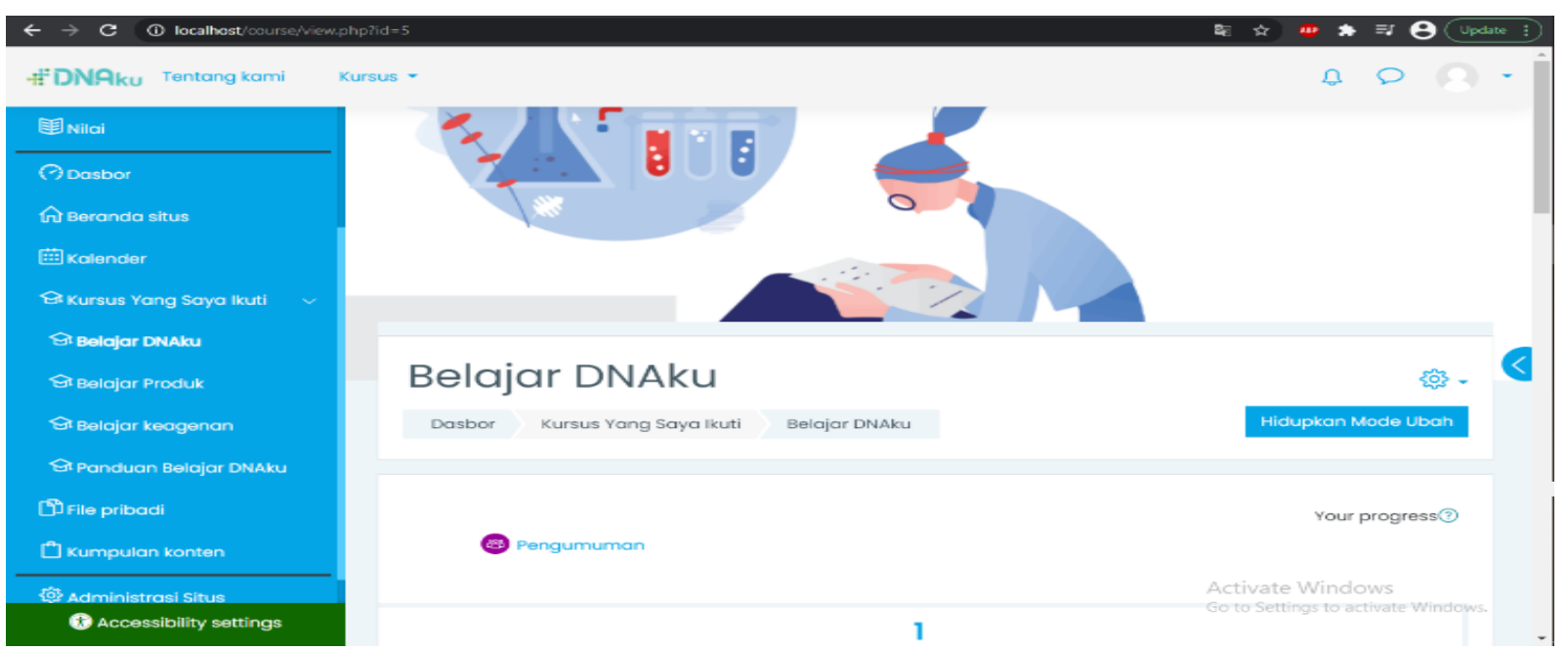

Gambar 6. Tampilan menu kursus

Pada tampilan menu kursus Admin dapat membuat dan mengupload materi dan beberapa test dan quiz untuk agent DNAku. Dan ada sebuah content interactive h5p yang dapat membuat content seperti video, audio, games agar pembelajaran semakin menarik.

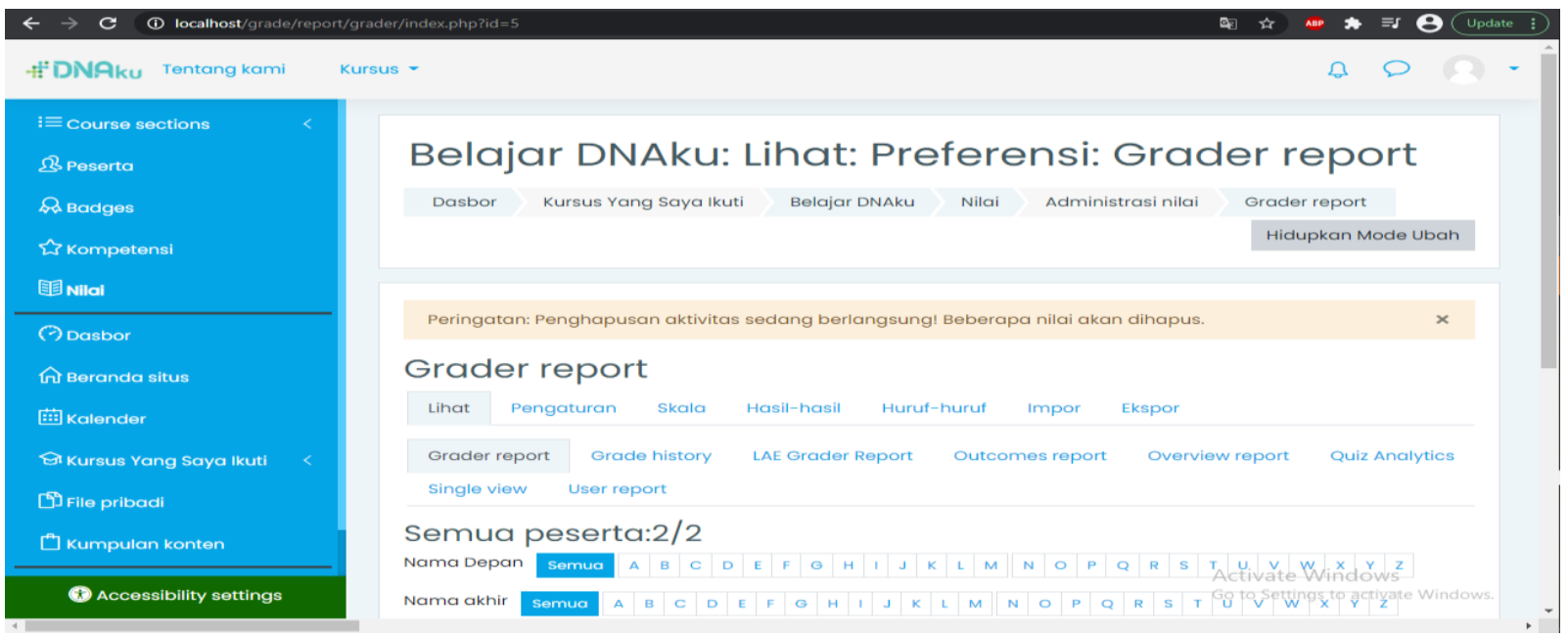

Gambar 7. Tampilan laporan nilai

Dalam tampilan laporan nilai adalah tampilan hasil dari nilai agent yang telah mengikuti quiz dan test akan ditampilkan bobot nilai sesuai kemampuan agent dalam menjawab soal. Dan juga admin dapat mengupdate data nilai dari masing masing agent. 


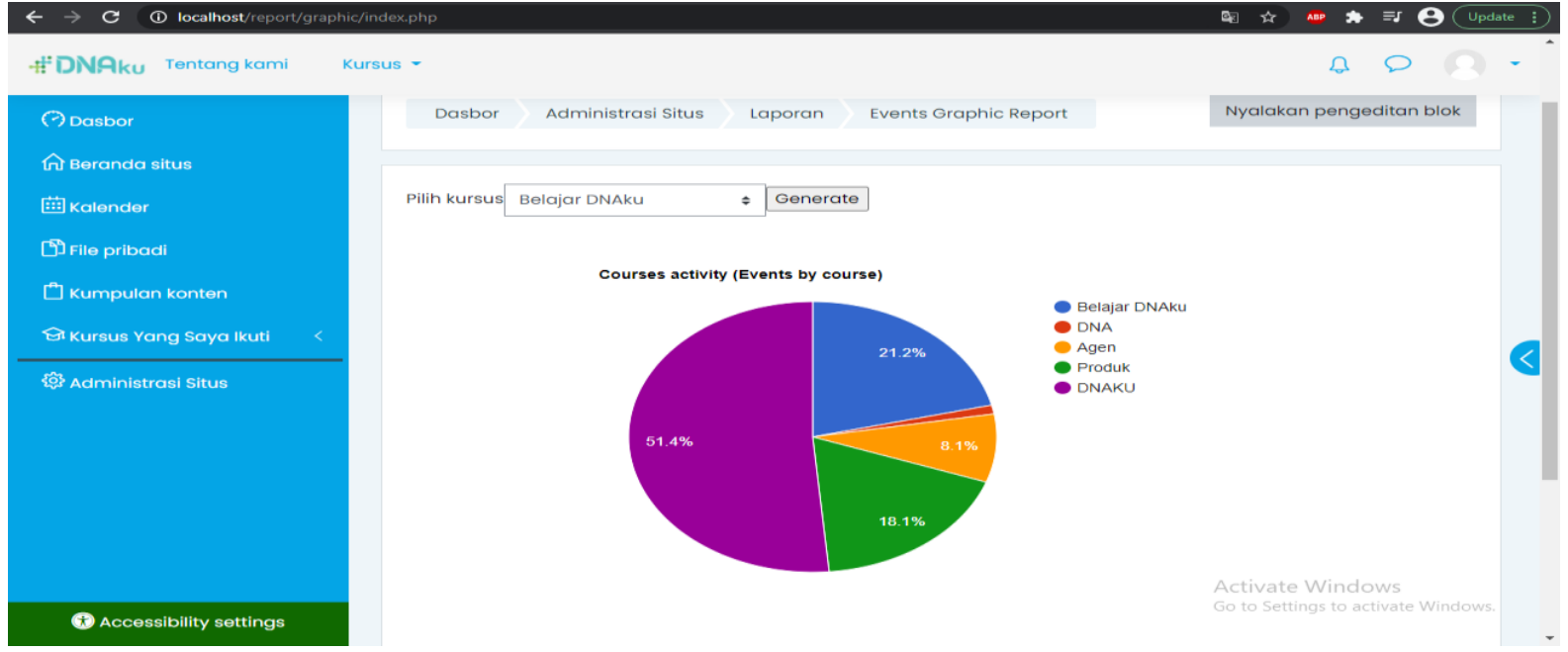

Gambar 8. Grafik activity agent

Pada tampilan diagram activity agent adalah seluruh kegiatan yang dilakukan agent selama mengakses system e-learning. Dalam diagram di atas juga menjelaskan kecenderungan agent dalam melakukan kegiatan pembelajaran sehingga admin perusahaan mengetahui keaktifan agent selamat mengakses system e-learning tersebut.

\section{KESIMPULAN}

Berdasarkan penelitian yang telah dilakukan dapat disimpulkan, system e-learning yang dikembangkan dan diimplementasikan sudah sesuai dengan kebutuhan dalam pembuatan e-learning. System yang dibuat membantu agent dan atasan dalam proses pembelajaran internal PT.Global Infotech Solution. Hasil dari pengujian menunjukan system e-learning yang dibuat sesuai dengan yang developer harapakan. Untuk pengembangan selanjutnya system e-learning ini dapat ditambah dengan fitur yang sesuai dengan kebutuhan dalam mengakses pembelajaran.

\section{REFERENCES}

[1] P. D. A. N. I. E-learning, M. Moodle, and D. A. N. Vicon, "DEVELOPING AND IMPLEMENTING E-LEARNING USING MOODLE," vol. 6, no. 1, 2016.

[2] R. Arofah and H. Cahyadi, "Pengembangan Bahan Ajar Berbasis ADDIE Model," vol. 3, no. 1, pp. 35-43, 2019.

[3] A. Setiawan and Z. A. Trimiarsih, "IMPLEMENTASI E-LEARNING DENGAN PENDEKATAN," vol. 2012, no. Snati, pp. 15-16, 2012.

[4] R. Laipaka, "Pengembangan dan Implementasi E-Learning pada AMIK JTC Semarang," pp. 301-306.

[5] I. Permatasari, "Pengaruh E-Learning Sebagai Media Pelatihan dan Pengembangan Terhadap Kinerja Karyawan BCA KCU Tangerang," vol. 07 , pp. $1-8,2018$.

[6] N. Maluku, "IMPLEMENTATION OF E-LEARNING SYSTEM USING THE SOFTWARE MOODLE," vol. 1, no. September, 2016.

[7] D. K. Widyawati and I. S. Sitanggang, "Analisis Kebutuhan Pengembangan E-Learning Politeknik Negeri Lampung Analysis Of Need For E-Learning Development State Politechnic Of Lampung,” no. September, pp. 292-301, 2017. 